\title{
COLLABORATION ONLINE: SLOAN-C RESOURCES
}

Janet C. Moore

The Sloan Consortium

\begin{abstract}
Over the years, insights about ALN collaboration from Sloan-C's annual publications in the quality series, in Effective Practices, and in The Journal of Asynchronous Learning Networks (JALN), have been useful for refining theoretical and practical knowledge about online education. This summary points to additional resources related to collaboration.
\end{abstract}

\section{KEYWORDS}

Asynchronous Learning Networks (ALNs), Collaboration, Interaction

\section{INTRODUCTION}

Opportunities for collaboration are the internet's greatest gift. As never before, asynchronous learning networks (ALNs) enable rapid dissemination, testing, feedback application and refinement of ideas [1. 2]. ALN increases the potential for collaboration among people with diverse perspectives, who can now much more easily collaborate from widespread locations and contexts. Thus, the networks in ALN emphasize not just technological networks, but networks of people [3, 4].

\section{COLLABORATION AND LEARNERS}

Trust and common purpose characterize learning communities that collaborate successfully. Rovai's influential paper, A Preliminary Look at the Structural Differences of Higher Education Classroom Communities in Traditional and ALN Courses [5], identifies and provides metrics for the elements of community in online environments, including attitudes about safety, acceptance, critical thinking, absence of confusion and group identity.

Peer-to-peer interactions [6] are one of the most influential features of online courses as Aviv and colleagues point out in "Reciprocity Analysis of Online Learning Networks"- "To develop reciprocity, learners have to go through a process of assessment of risks, rewards and likelihood of reciprocation" [7]. Assessing risks and rewards can be a major challenge to learners as they discover that learning online requires significant role adjustment. In Student Role Adjustment in Online Communities of Inquiry: Model and Instrument Validation, Garrison, Cleveland-Innes, and Fung explain that:

Inevitably, the student must assume greater responsibility to match the increased control that comes with online learning. This is compounded by the intellectual demands of the precision of written communication. In combining both the freedom and demands of online communication, participants must move from a relatively passive classroom experience into a more active online community of inquiry [8]. 
Welcoming, easily accessible orientation and ongoing support for faculty [9] and students [10] are invaluable [11] aids for role adjustment.

Within classes, the feelings of community that support effective collaboration grow gradually. Observing how trust and common purpose emerge in online groups, Brown details three stages of community in online environments in The Process of Community-Building in Distance Learning Classes [12]. Brown shows that communities develop from introductions, to in-depth discussions, to camaraderie. In each phase, engagement increases. Brown points out that veteran online learners can reach out to novices to help them adjust. At Mercy College, veteran students, known as wizards, have been such an effective support network for their peers and also for instructors that drop out rates have decreased by $50 \%$. Mercy College's Master of Science in Organizational Behavior also emphasizes cohorts to build its online learning community so that whether students are studying online or face-to-face, they always have access to each other and to their mentors. Mercy College is careful to define effective participation so that students understand the collaborative nature of online classes.

Nevertheless, community too frequently grows unevenly, according to Rovai and Ponton in An Examination of Sense of Classroom Community and Learning Among African American and Caucasian Graduate Students because "text-based computer-mediated communication...possesses reduced social cues (e.g., voice inflection and facial expressions), which can lead to misunderstandings": "insufficient interactions of students with peers and faculty and differences with the prevailing value patterns of other students are likely to result in students who feel they do not fit in, which, in turn, may result in a weak sense of community due to lack of engagement, feelings of isolation, and poor academic performance" [13]. The climate for collaboration is also affected by gender [14, 15, 16], generation [17], and cultural context [18]. Thus, Swan and Shih point out the importance of presence, finding that high perceptions of presence- "the degree to which participants in computer-mediated communication feel affectively connected one to another"-correlate with high perceptions of learning [19].

"Strive for presence" [20], advises Pelz, who shares specific, inclusive strategies for building learning community among classmates by using active learning with interaction among students of diverse talents and ways of learning [21], and constructivist and challenge- or problem-based assignments [22] in classes that foreground cognitive, social, and teaching presence [23]. Drawing on a decade of ongoing research at the State University of New York Learning Networks [see especially 24, 25, 26, 27, 28] and effective practices in learning effectiveness, cost effectiveness and institutional commitment, access and faculty and student satisfaction, Shea provides this framework: 


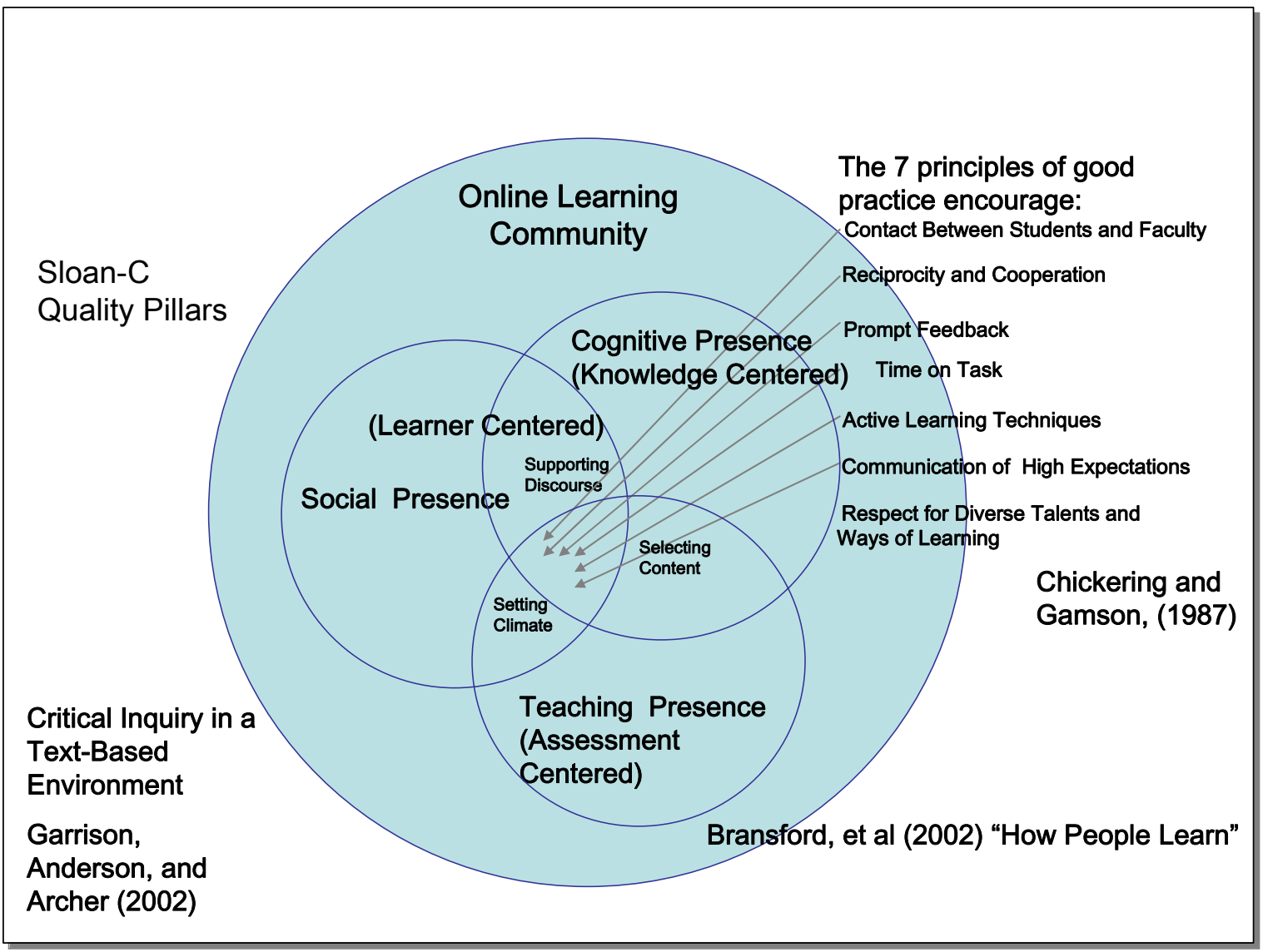

Figure 1. A Conceptual Framework for High Quality, Higher Education, Online Learning [29]

\section{COLLABORATION AND ASSESSMENT}

Collaborative learning pedagogy shifts the focus from the teacher-student interaction to the role of peer relationships in educational success... Group members learn by virtue of mediating socio-emotional variables (such as motivation, reduced anxiety, or satisfaction) that create an emotional or intellectual climate favorable to learning. When working with peers instead of alone (or with the instructor), anxiety and uncertainty are reduced as learners find their ways through complex or new tasks. These effects tend to increase motivation and satisfaction with the learning process in general.

So observe Hiltz and colleagues in Measuring the Importance of Collaborative Learning for the Effectiveness of ALN: A Multi-Measure, Multi-Method Approach [30].

Too often interaction may be conflated with collaboration [13], but Hiltz and colleagues note that true collaborative learning activities can include "seminar-style presentations and discussions (in which students are the teachers), debates, group projects, simulation and role-playing exercises, and collaborative composition of essays, exam questions, web pages, stories, research plans, or other artifacts that demonstrate the knowledge and skills that are the subject of the course” [10].

Conversely, it's also possible that classmates may experience strong community without learning much. Thus in "ALN Research: What We Know and What We Need To Know About Contextual Influences," Hiltz, Arbaugh, and Benbunan-Fich propose that measurements of learning across classes, courses, 
institutions, organizations and cultures should consider the wide range of variables:

1. the technology (in particular, the media mix);

2. the group (course or class), and the organizational setting (college or university), which define the context in which the technology is used;

3. the instructor; and

4. the individual student [31].

Too often these variables have not been taken into account in assessing what's most valuable about learning online.

In fact, in Considerations For Developing Evaluations of Online Courses, Achtemeier found that most schools do not evaluate online courses according to best practices for effective teaching and learning in online courses, and she describes the new rubrics developed by the University System of Georgia that do focus on best ALN practices, including collaboration among students [32]. Applying more appropriate measures to specifically online learning is also the subject of Meyer's Evaluating Online Discussions: Four Different Frames of Analysis, Meyer examines collaborative discussions using four frames-a reflective judgment model; a model of intellectual and ethical development; a four-stage critical-thinking model; and Bloom's taxonomy of educational objectives [33]. Roblyer and Ekhaml created a rubric to measure the effectiveness of interaction by considering four areas:

- Social rapport-building activities created by the instructor;

- Instructional designs for learning created by the instructor;

- Levels of interactivity of technology resources;

- Impact of interactive qualities as reflected in learner response [34].

In Exploring the Interaction Equation: Validating a Rubric to Assess and Encourage Interaction in Distance Courses, Roblyer and Wienecke observe that

A rubric which is a valid, reliable measure of various aspects of interaction in distance courses can be used to encourage interaction by students and instructors, as well as to measure how much students perceive it has occurred in given courses. It can also provide valuable feedback for instructors seeking to improve the quality of their online courses [35].

Using the best that is known about interactive online environments, QualityMatters has designed a rubric that enables educators to design their courses and to obtain feedback on design from their peers across multiple institutions. Such inter-institutional collaborative efforts, as Sener suggests [36], are among the most significant opportunities for improving quality.

\section{COLLABORATION AND KNOWLEDGE}

Swan's primer on constructivism, “A Constructivist Model for Thinking about Learning Online” [37] explains how online environments support active mental construction that is linked to interactions with the environment:

Learner-centered teaching...recognizes the importance of building on the conceptual and cultural knowledge that students bring with them to the learning experience, of linking learning to students' experiences, and of accepting and exploring multiple perspectives and divergent understandings. At the same time, learner-centered teaching must be concerned with diagnosing and remediating students' misconceptions. Constructivism suggests that such remediation 
requires accommodation - that is, that teachers must help students to make their thinking visible, to test it against experience, and to reconstruct more viable understandings. [30]

In this light, some online collaborations are especially innovative and noteworthy. For example, beginning with a review of the theoretical foundations of constructivism and an evaluation of methods for discourse analysis, Milton Campos's A Constructivist Method for the Analysis of Networked Cognitive Communication and the Assessment of Collaborative Learning and Knowledge-Building demonstrates how a class of nurses collaborated to create a contract to help motivate heart patients to practice heart-healthy self-care. Also involved in improving the quality of healthcare through online collaboration is the Institute for Healthcare Improvement (IHI). IHI measures improvement through online collaborations among the worldwide community of people who systematically implement changes and report back to each other about successes [38].

- At the New Jersey Institute of Technology, collaborations are designed to involve students in constructing and making meaning visible.

- In "Collaborative Assessment in Asynchronous Learning Networks: Research in Progress" [39], Shen and colleagues advocate collaboration in learner-centered assessment proposing to shift the attention in assessment from instructors and teaching to students and learning.

- In 'Effectively Managing Large Enrollment Courses: A Case Study” [40], NJIT uses collaboration to encourage an atmosphere for sharing knowledge; students are grouped into cohorts to discuss topics and report back to the group so that the volume of postings is manageable.

- With The Delphi Process as a Collaborative Learning Method, all students participate in a classwide, collaborative, structured learning exercise to generate ideas, organize responses, reduce information overload, expose disagreements, evaluate ideas, and solve problems [41].

- In Participatory Examinations in Asynchronous Learning Networks: Longitudinal Evaluation Results students make up questions, answer other students' questions, grade answers to questions they author, and appeal grades.

Originating with the University of Massachusetts, the real-time case method used collaboration to enhance learning and reduce new product costs. Students from four universities collaborated on studying the case of a real company to develop and deliver "inexpensive and virtually instantaneous publication of multimedia materials for worldwide access.” Bisson and colleagues also used inter-institutional collaboration for entrepreneurship education involving 5 professors at three universities and "created a synergy and net gains in the educational experience that could not have been achieved in the physical classroom" [42]. Also especially notable as inter-institutional collaboratives to which many faculty contribute are repositories such as LON-CAPA and Merlot.

As McCurdy and Schroeder note in this issue [43], collaborations among online educators are fruitful. For example, in Spring 2004, Sloan-C conducted an online collaborative workshop in which teams of educators from 170 schools, 11 countries, and 43 U.S. states shared questions and answers in response to challenges about online learning. An example of a collaborative publication that this group produced is ALN Principles for Blended Environments [44]. So effective are collaborations among online faculty, that at least one institution has formalized faculty collaboration to design its entire curriculum, and then to share the collaborative process with other institutions. In “Model-Driven Design,” Laster describes Babson's interdisciplinary collaboration for "a highly orchestrated design [that] shows how to develop and deliver curricula that teach complex concepts and skills with multi-disciplinary input, with continuous refinement, and with technologies and traditional educational activities that achieve clear learning outcomes” [45]. Babson shares its model with other institutions who wish to adapt it for their own environments. 


\section{CONCLUSION}

The people cited in this tenth anniversary issue of the Journal of Asynchronous Learning Networks are among the first to glimpse the power of collaborations that can grow on an unprecedented scale and with an immediacy and diversity nearly unimaginable before now. From the birth of Western formal education in Plato's academy, learning has depended on "dialogue and collaborative problem-solving... in which participants consent to have their ideas and opinions exposed to examination and criticism by the group" [46]. As a legacy that is also an innovation, collaborative technology drives "profound, rapid and discontinuous” [47] cultural change. We are only beginning to realize its value.

\section{ABOUT THE AUTHOR}

Janet C. Moore, Ph.D. is the Chief Learning Officer for the Sloan Consortium. She helps edit the Sloan$C$ View, the Journal of Asynchronous Learning Networks, and volumes in the annual Sloan-C quality series. She helps design and conduct Sloan-C workshops and seminars, and administers Sloan-C Catalog reviews; she is the managing editor for Sloan-C effective practices, and project manager for the eArmyU Council of Academic Management.

\section{REFERENCES}

1. Hiltz, S. R. and M. Turoff. Network Nation: Human Communication via Computer. Boston, MA: MIT Press, revised edition, 1993. Originally published in 1978.

2. Coming to terms. The Sloan-C View 2(4): June 2003. http://www.sloan-c.org/publications/view /v2n4/coverv2n4.htm.

3. Mayadas, F. Testimony to the Kerrey Commission on Web-based Education. Journal of Asynchronous Learning Networks 5(1): June 2001. http://www.sloan-c.org/publications/jaln/v5n1 /v5n1 mayadas.asp.

4. Gomory, R. E. Sheffield Lecture-Yale University, January 11, 2000, Internet Learning: Is it Real and What Does it Mean for Universities? Journal of Asynchronous Learning Networks 1(5): June 2001. http://www.sloan-c.org/publications/jaln/v5n1/v5n1 gomory.asp.

5. Rovai, A. A preliminary look at the structural differences of higher education classroom communities in traditional and ALN courses. Journal of Asynchronous Learning Networks 6(1): July 2002. http://sloan-c.org/publications/jaln/v6n1/v6n1_rovai.asp.

6. Please see Karen Swan's summary of research on the kinds of interaction and their implications for practice: "Relationships between Interactions and Learning In Online Environments" is available at http://www.sloan-c.org/publications/books/interactions.pdf.

7. Aviv, R., Z. Erlich \& G. Ravid. Reciprocity analysis of online learning networks. In J. C. Moore (ed.), Elements of Quality Online Education: Engaging Communities, Wisdom from the Sloan Consortium, Vol. 2 in the Wisdom Series. Needham, MA: Sloan-C, 2005. Also available in Journal of Asynchronous Learning Networks 9(4): December 2005 (with login).

8. Garrison, D. R., M. Cleveland-Innes, and T. Fung. Student role adjustment in online communities of inquiry: Model and instrument validation. Journal of Asynchronous Learning Networks 8(2): April 2004. http://www.sloan-c.org/publications/jaln/v8n2/v8n2_garrison.asp.

9. Sloan-C schools have shared orientation and support tips for faculty in Sloan-C Effective Practices. The links lead to effective practices from: Berkeley College, Boise State University, California State University, Chico, Florida Community College at Jacksonville, Florida State University, George Mason University, Indiana Partnership for Statewide Education, Maryland Online, Monroe County Community College, South Yorkshire Further Education Consortium, SUNY, University of Nebraska at Lincoln, University of Washington. 
10. Sloan-C schools have shared orientation and support tips for students in Sloan-C Effective Practices. The links lead to effective practices from: Arizona Regents University, Community College of Baltimore County, Illinois Virtual Campus, Old Dominion University, Saint Leo University, Western Governors University.

11. Thompson, M. and J. McGrath. Using ALNs to support a complete educational experience. Journal of Asynchronous Learning Networks 3(2): November, 1999. http://www.sloan-c.org/publications /jaln/v3n2/v3n2_thompson.asp.

12. Brown, R. The process of community-building in distance learning classes. Journal of Asynchronous Learning Networks 5(2): September 2001. http://www.sloan-c.org/publications/jaln/v5n2/v5n2 brown.asp.

13. Rovai, A. and M. Ponton. An examination of sense of classroom community and learning among African American and Caucasian graduate students. Journal of Asynchronous Learning Networks 9(3): October 2005. http://www.sloan-c.org/publications/jaln/v9n3/v9n3 rovai.asp.

14. Graddy, D. B. Gender and online discourse in the principles of economics. Journal of Asynchronous Learning Networks 8(4): December 2004. http://www.sloan-c.org/publications/jaln/v8n4/v8n4 graddy.asp.

15. Gunn, C., M. McSporran, H. Macleod, and S. French. Dominant or different? Gender issues in computer supported learning. Journal of Asynchronous Learning Networks 7(1): February 2002. http://www.sloan-c.org/publications/jaln/v7n1/v7n1_gunn.asp.

16. Ory, J.C., C. Bullock, and K. Bumaska. Gender similarity in the use of and attitudes about ALN in a university setting. Journal of Asynchronous Learning Networks 1(1): March 1997. http://www.sloan-c.org/publications/jaln/v1n1/v1n1_ory.asp.

17. Dziuban, C. P. Moskal, and J. Hartman. Higher education, blended learning and the generations: Knowledge is power-No more. In J. Bourne and J.C. Moore, eds. Elements of Quality Online Education: Engaging Communities, Volume 6 in the Sloan-C series. Needham, MA, Sloan-C: 2005.

18. Morse, K. Does one size fit all? Exploring asynchronous learning in a multicultural environment. Journal of Asynchronous Learning Networks 7(1): February 2003. http://www.sloan-c.org /publications/jaln/v7n1/v7n1_morse.asp.

19. Swan, K. and L. F. Shih. On the nature and development of social presence in online course discussions. Journal of Asynchronous Learning Networks 9(3): October 2005. http://www.sloan-c.org /publications/jaln/v9n3/v9n3_swan.asp.

20. Pelz, W. (My) Three principles of effective online pedagogy. Journal of Asynchronous Learning Networks 8(3): June 2004. http://www.sloan-c.org/publications/jaln/v8n3/v8n3_pelz.asp.

21. Chickering, A. and S. C. Ehrmann. Implementing the seven principles: Technology as lever. AAHE Bulletin: 3-6, October, 1996. http://www.tltgroup.org/programs/seven.html.

22. Bransford, J. D., A. L. Brown, \& R. R. Cocking. (Eds.) How People Learn: Brain, Mind, Experience, and School. Washington, D.C.: National Academy Press, 1999. http://www.nap.edu/html/howpeople1/.

23. Garrison, D. R., T. Anderson, and W. Archer. Critical inquiry in a text-based environment: computer conferencing in higher education. Internet and Higher Education 11(2): 1-14, 2000. http://communitiesofinquiry.com/documents/CTinTextEnvFinal.pdf.

24. Shea, P., C. S. Li, K. Swan, and A. Pickett. Developing learning community in online asynchronous college courses: The role of teaching presence. Journal of Asynchronous Learning Networks 9(4): December 2005. http://www.sloan-c.org/publications/jaln/v9n4/index.asp (full article with log-in).

25. Shea, P., K. Swan, and A. Pickett. Teaching presence and establishment of community in online learning environments. In J.C. Moore (ed.), Engaging Communities: Wisdom from the Sloan Consortium. Needham, MA: Sloan-C, 2005.

26. Shea, P., A. Pickett, and W. Pelz. Enhancing student satisfaction through faculty development: The importance of teaching presence. In J. Bourne and J.C. Moore (eds.), Elements of Quality Online Education: Into the Mainstream, Volume 5 in the Sloan-C series. Needham, MA: Sloan-C, 2003. 
27. Shea, P, K. Swan, E. Fredericksen, and A. Pickett. Student satisfaction and reported learning in the SUNY Learning Network. In J. Bourne and J.C. Moore (eds.), Elements of Quality Online Education, Needham, MA: Sloan-C, 2002.

28. Shea, P., W. Pelz, E. Fredericksen, and A. Pickett. Online teaching as a catalyst for classroombased instructional transformation. In J. Bourne and J.C. Moore (eds.), Elements of Quality Online Education. Needham, MA: Sloan-C, 2002.

29. Shea, P. Plenary address on interaction. Sloan-C Online Research Workshop. March, 2004; and presentation at the Sloan-C Workshop on Blended Learning, University of Chicago, April 2005.

30. Hiltz, S. R., J. B. Arbaugh, N. Rotter, and R. Benbunan-Fich. Measuring the importance of collaborative learning for the effectiveness of ALN: A multi-measure, multi-method approach. Journal of Asynchronous Learning Networks 4(2): September 2000. http://www.sloan-c.org /publications/jaln/v4n2/v4n2_hiltz.asp.

31. Hiltz, S. R, J. B. Arbaugh, R. Benbunan-Fich, and P. Shea. ALN research: What we know and what we need to know about contextual influences. In J.R. Bourne and J.C. Moore (eds.), Elements of Quality Online Education: Into the Mainstream, Volume 5 in the Sloan-C series. Needham, MA: Sloan-C, 2003.

32. Achtemeier, S. D., L. Morris, and C. L. Finnegan. Considerations for developing evaluations of online courses. Journal of Asynchronous Learning Networks 7(1): February 2003. http://www.sloanc.org/publications/jaln/v7n1/v7n1_achtemeier.asp.

33. Meyer, K. A. Evaluating online discussions: Four different frames of analysis. Journal of Asynchronous Learning Networks 8(2): April 2004. http://sloan-c.org/publications/jaln/v8n2 /v8n2_meyer.asp.

34. Roblyer, M. D., \& L. Ekhaml. How interactive are YOUR distance courses? A rubric for assessing interaction in distance learning. The Online Journal of Distance Learning Administration 3(2): Summer 2000. http://www.westga.edu/ distance/roblyer32.html.

35. Roblyer, M. D. and W. R. Wiencke. Exploring the interaction equation: Validating a rubric to assess and encourage interaction in distance courses. Journal of Asynchronous Learning Networks 8(4): December 2004. http://www.sloan-c.org/publications/jaln/v8n4/v8n4 roblyer.asp.

36. Sener, J. Quality Matters: Inter-institutional quality improvement for online courses. Journal of Asynchronous Learning Networks 10(1): February 2006.

37. Swan, K. A constructivist model for thinking about online learning. In J. Bourne and J. C. Moore (eds.), Elements of Quality Online Education: Engaging Communities, Volume 6 in the Sloan-C series. Needham, MA: Sloan-C: 2005.

38. Carver, P. and B. Boushon. The virtual breakthrough series collaborative at the Institute for Healthcare Improvement. In J. C. Moore (ed.), Engaging Communities: Wisdom from the Sloan Consortium. Needham, MA: Sloan-C, 2005.

39. Shen, J., S. R. Hiltz, and M. Bieber. Collaborative assessment in asynchronous learning networks: Research in progress. In J. C. Moore (ed.), Elements of Quality Online Education: Engaging Communities, Wisdom from the Sloan Consortium. Needham, MA: Sloan-C: 2005.

40. Turoff, M. and S. R. Hiltz. Effectively managing large enrollment courses: A case study. In J. Bourne and J. C .Moore (eds.), Online Education. Needham, MA, Sloan-C: 2001.

41. Turoff, M., S. R. Hiltz, Z. Li, Y. Wang, and H. K. Cho. The Delphi process as a collaborative learning method. In J. C. Moore (ed.), Elements of Quality Online Education: Into the Mainstream: Wisdom from the Sloan Consortium. Needham, MA: Sloan-C: 2004.

42. Bisson, B., E. Leach, T. Little, R. Richards, B. Veitch, and K. Zundel. A case study in blended learning: Leveraging technology in entrepreneurship education. In J. Bourne and J. C. Moore (eds.), Elements of Quality Online Education: Engaging Communities, Volume 6 in the Sloan-C series. Needham, MA: Sloan-C, 2005.

43. McCurdy, S. and R. Schroeder. Achieving diversity through online inter-institutional collaborations. Journal of Asynchronous Learning Networks 10(1): February 2006. 
44. Multiple authors. ALN Principles for Blended Environments. Needham, MA: Sloan-C, May 2004. http://www.sloan-c.org/publications/books/alnprinciples2.pdf.

45. Laster, S. Model-driven design: Systematically building integrated blended learning experiences. In J. Bourne and J. C. Moore (eds.), Elements of Quality Online Education: Into the Mainstream, Volume 5 in the Sloan-C Series. Needham, MA: Sloan-C, 2004.

46. Scorza, J. Do online students dream of electric teachers? Journal of Asynchronous Learning Networks 9(2): June 2005. http://www.sloan-c.org/publications/jaln/v9n2/v9n2_scorza_member.asp.

47. Preparing for the Revolution: Information Technology and the Future of the Research Universities. Panel on the Impact of Information Technology on the Future of the Research University, Policy and Global Affairs, National Research Council. October, 2002. http://www.nap.edu/catalog/10545.html. 